\title{
Preclinical development and first-in-human study of ATX-MS-1467 for immunotherapy of MS
}

\section{OPEN}

Heather B. Streeter, PhD

Rachel Rigden, $\mathrm{PhD}$

Keith F. Martin, PhD

Neil J. Scolding, PhD, FRCP

David C. Wraith, PhD

Correspondence to

Dr. Wraith:

d.c.wraith@bris.ac.uk

\section{ABSTRACT}

Objective: The study was designed to test the efficacy of ATX-MS-1467 in a relevant preclinical model and to assess its safety for the treatment of patients with secondary progressive multiple sclerosis (SPMS).

Methods: ATX-MS-1467 was tested for its ability to suppress experimental autoimmune encephalomyelitis (EAE) in the (Ob $\times$ DR2)F1 mouse both before and after disease onset. Safety was assessed by clinical assessment, MRI analysis, and the measurement of immune responses to self- and nonself-antigens in patients with SPMS.

Results: ATX-MS-1467 displayed a dose-dependent inhibition of EAE and was more effective than glatiramer acetate in the treatment of ongoing disease in humanized mice. A phase 1 open-label dose-escalating study demonstrated that ATX-MS-1467 was safe and welltolerated in a group of 6 patients with SPMS, up to a dose of $800 \mu \mathrm{g}$.

Conclusions: The results of this study support further development of ATX-MS-1467 in a clinical trial powered to investigate the immunologic and clinical benefits of treatment in relapsingremitting MS.

Classification of evidence: This study provides Class IV evidence that ATX-MS-1467 is safe and tolerated in a group of 6 patients with SPMS. Neurol Neuroimmunol Neuroinflamm 2015;2:e93; doi: 10.1212/ NXI.0000000000000093

\section{GLOSSARY}

$\mathbf{A E}=$ adverse event; $\mathbf{A P C}=$ antigen-presenting cells; $\mathbf{B C G}=$ bacillus Calmette-Guérin; $\mathbf{E A E}=$ experimental autoimmune encephalomyelitis; EDSS = Expanded Disability Status Scale; GA = glatiramer acetate; HLA = human leukocyte antigen; IFN = interferon; IL = interleukin; IMP = investigational medicinal product; $\mathbf{M B P}=$ myelin basic protein; $\mathbf{M H C}=$ major histocompatibility complex; $\mathbf{M S}=$ multiple sclerosis; PBMC = peripheral blood mononuclear cells; PPD = purified protein derivative; SPMS = secondary progressive MS.

By focusing on pathogenic mechanisms, emerging therapies for multiple sclerosis (MS) promise to be more potent than currently approved drugs, although they retain the potential for serious adverse effects. ${ }^{1}$ The exception to this is antigen-specific immunotherapy, since this aims to reinstate tolerance to the protein causing the disease. ${ }^{2}$ This approach has been applied in the field of allergy for more than 100 years; however, it has not transferred successfully to autoimmunity because of complications arising from immune responses to the administered antigens. We have shown that these complications are avoided by use of $\mathrm{CD}^{+}{ }^{+} \mathrm{T}$-cell epitopes for tolerance induction. ${ }^{3}$ We have shown that peptides must mimic the naturally processed T-cell epitope to induce tolerance ${ }^{4}$ and have defined the term apitope (antigen processing independent epitope) for peptides that bind directly to major histocompatibility complex (MHC) class II on immature dendritic cells, ${ }^{5}$ the cells responsible for peripheral tolerance in the immune system. ${ }^{6}$ Treatment with soluble peptides inhibits both Th1 and Th2 immune responses, ${ }^{7}$ enhances interleukin (IL)-10 secretion, ${ }^{8}$ and induces a negative feedback regulatory mechanism. ${ }^{9}$ Antigen-specific immunotherapy with peptides suppresses CNS inflammation in rodent models of $\mathrm{MS}^{10-12}$ and is showing

From Apitope Technology Bristol Ltd. (H.B.S., R.R., K.F.M., D.C.W.), Bristol UK; School of Cellular and Molecular Medicine (H.B.S., D.C.W.) and School of Clinical Sciences (N.J.S.), University of Bristol, UK; and Southmead Hospital (N.J.S.), Bristol, UK.

Funding information and disclosures are provided at the end of the article. Go to Neurology.org/nn for full disclosure forms. The Article Processing Charge was paid by Emma Baldwin, Apitope International NV.

This is an open access article distributed under the terms of the Creative Commons Attribution-Noncommercial No Derivative 3.0 License, which permits downloading and sharing the work provided it is properly cited. The work cannot be changed in any way or used commercially. 
promise in the clinic. ${ }^{13}$ We showed previously that $\mathrm{T}$ cells from patients with MS respond to epitopes from 8 regions of myelin basic protein (MBP), ${ }^{14}$ with 5 regions being recognized most frequently. Here we show that 4 of these epitopes behave as apitopes. A cocktail of these peptides (ATX-MS-1467) can suppress experimental autoimmune encephalomyelitis (EAE) in a humanized mouse model. Furthermore, a phase 1 trial of antigen-specific immunotherapy with ATX-MS-1467 has shown that treatment with this apitope cocktail is safe and well-tolerated in a group of 6 patients with secondary progressive MS (SPMS).

METHODS Primary research questions. The study was designed to test the efficacy of ATX-MS-1467 in a relevant preclinical model and to assess its safety for the treatment of SPMS.

Ethics statements. Animal experiments were carried out under a UK Home Office Project License and were reviewed by the University of Bristol Ethical Review Committee. Consent documents for the phase 1 trial were given by the Medicines and Healthcare Products Regulatory Agency and the local research ethics committee (EudraCT No. 2006-004329-27).

ATX-MS-1467. ATX-MS-1467, an equal parts mixture of synthetic peptides ATX-MS1 (MBP30-44), ATX-MS4 (MBP131145), ATX-MS6 (MBP140-154), and ATX-MS7 (MBP83-99) in phosphate- buffered saline (PBS), is manufactured by Bachem (Bubendorf, Switzerland) and formulated by Nova Laboratories (Wigston, UK). Peptides were characterized (table 1) by measuring ${ }^{3} \mathrm{H}$-thymidine incorporation of $\mathrm{T}$-cell clones specific for $\mathrm{MBP}^{14}$ using live or paraformaldehyde-fixed antigenpresenting cells $(\mathrm{APC})^{15}$ or using the Proimmune REVEAL assay (Oxford, UK).

Mice and EAE. (Ob x DR2)F1 mice $^{16}$ were provided by Prof. Lars Fugger and maintained at the University of Bristol. Mice were immunized subcutaneously at the base of tail with an emulsion composed of $100 \mu \mathrm{g}$ of spinal cord homogenate in Freund complete adjuvant and Mycobacterium tuberculosis H37RA $(4 \mathrm{mg} / \mathrm{mL}$ final concentration) (Difco; Becton, Dickinson and Company, Oxford, UK). This was followed by $200 \mathrm{ng}$ of pertussis toxin (Sigma-Aldrich, Gillingham, UK) in PBS injected intraperitoneally on days 0 and 2. Groups of 10-20 mice were injected subcutaneously with $100 \mu \mathrm{L}$ of clinical-grade ATX-MS-1467 twice weekly. Experiments including both male and female mice had equivalent numbers of age- and sex-matched animals in treatment and control (PBS) groups. Treatment with ATX-MS-1467 was compared with clinical-grade glatiramer acetate (GA), since GA is the only approved peptide immunotherapy for MS. GA was given subcutaneously at $2 \mathrm{mg}$ daily. Clinical signs of EAE were scored by 2 independent observers as follows: 0 , no disease; 1 , flaccid tail; 2 , impaired righting reflex and/or partial hind leg paralysis; 3 , total hind limb paralysis; 4 , fore and hind limb paralysis; 5 , moribund or dead. ${ }^{11}$

Phase 1 study design. Adult patients with $\mathrm{SPMS}^{17}$ were recruited from the MS Database at North Bristol NHS Trust. Women of childbearing potential were to use 2 forms of medically acceptable contraception and were required to have a negative pregnancy test. Men were to use medically acceptable contraception. Patients were excluded from the trial if they had taken interferon (IFN) $\beta$ or any other immune treatment within the past 12 months, had received steroid treatment or had had a documented relapse during the 3 months prior to screening, were pregnant or breastfeeding, had MRI claustrophobia, had significant medical or psychiatric conditions, had undergone major surgery in the previous 4 weeks, had any other autoimmune disease or a gadolinium allergy, or had participated in another clinical trial in the 12 months prior to the first dose of ATX-MS-1467. Six of 8 patients satisfied the inclusion criteria: 2 men and 4 women with a median age of 50 years (range 37-68 years), a median duration since disease onset of 11.5 years (range 11-21 years), a median duration of the secondary progressive phase of 5.5 years (range 3-11 years), and a median Expanded Disability Status Scale (EDSS) score ${ }^{18}$ of 6.5 (range 5-7.5) at baseline. Informed consent was obtained from all the participating patients prior to screening.

Following screening (visit 1 at day -14), each patient received 6 intradermal injections of ATX-MS-1467 at different skin sites at 7- to 14-day intervals. Doses started at $25 \mu \mathrm{g}$ (visit 2 ) and then escalated to $50,100,400$, and $800 \mu \mathrm{g}$ (visits 3-6), followed by a second injection of $800 \mu \mathrm{g}$ (visit 7). Follow-up visits were at 1 month (visit 8) and 3 months (visit 9) after the last dose.

Screening at visit 1 included a comprehensive medical history, physical and neurologic examinations, blood sampling for routine

\begin{tabular}{|c|c|c|c|c|c|c|}
\hline \multirow{2}{*}{$\begin{array}{l}\text { Table } 1 \\
\text { MBP } \\
\text { epitope }\end{array}$} & \multicolumn{5}{|c|}{ Characterization of individual peptide epitopes from MBP } & \multirow[b]{2}{*}{$\begin{array}{l}\text { Apitope } \\
\text { number }\end{array}$} \\
\hline & Peptide sequence & $\begin{array}{l}\text { Presentation by } \\
\text { live APC }\end{array}$ & $\begin{array}{l}\text { Presentation by } \\
\text { fixed APC }\end{array}$ & $\begin{array}{l}\text { HLA restriction of epitope-specific } \\
\text { T-cell clones }\end{array}$ & $\begin{array}{l}\text { \% Stabilization of relevant } \\
\text { HLA class II molecule }\end{array}$ & \\
\hline $30-44$ & PRHRDTGILDSIGRF & + & + & DQ6 & 0 & MS1 \\
\hline 83-99 & ENPVVHFFKNIVTPRTP & + & + & DR2b & 42.7 & MS7 \\
\hline $130-144$ & RASDYKSAHKGFKGV & + & + & DQ6 & 0 & MS4 \\
\hline $140-154$ & GFKGVDAQGTLSKIF & + & + & $\mathrm{DR} 2 \mathrm{a}+\mathrm{DR} 2 \mathrm{~b}$ & 0 (DR2a) + 0 (DR2b) & MS6 \\
\hline $156-170$ & LGGRDSRSGSPMARR & + & - & NA & NA & NA \\
\hline
\end{tabular}

Abbreviations: APC = antigen-presenting cells; HLA = human leukocyte antigen; MBP = myelin basic protein; NA = not applicable.

This table summarizes the biochemical and immunologic properties of the peptide epitopes contained within ATX-MS-1467. Of the 8 antigenic regions in MBP, 5 epitopes gave more frequent responses among peripheral blood mononuclear cell samples from patients with multiple sclerosis. ${ }^{14}$ Four epitopes (MS1, 4, 6, and 7) were presented by both live and fixed APC and are defined as apitopes. Presentation of apitopes to MBP-specific T-cell clones was either HLA-DQ6 (MS1 and 4) or HLA-DR2 (MS 6 and 7) restricted. Surprisingly, however, only MS7 displayed sufficiently high affinity for major histocompatibility complex to stabilize relevant HLA restriction elements according to the Proimmune REVEAL assay (Oxford, UK). 
hematology and clinical biochemistry, immunoassay for preexisting antibodies against ATX-MS-1467, antinuclear and antithyroid autoantibodies, human leukocyte antigen (HLA) typing, and discussion about contraception. The screening visits were staggered to allow a minimum 7-day interval before first dosing of subsequent patients. Vital signs, body weight, pregnancy testing, and ECG were recorded at screening (visit 1) and repeated prior to each dose (visits 2-7) and at follow-up (visit 8). The patients remained in the ward for 24 hours after each dose. Vital signs and ECG were recorded at 1, 3, 6, and 24 hours. Safety blood tests for routine hematology and biochemical analysis, and urinalysis were performed at 3-6 hours and at 24 hours. Autoantibody tests were performed at 24 hours. On discharge, the patients were given a diary card to note any local injection site reactions and any medications taken until the next visit. During the dosing period, safety was assessed via a review of the adverse events (AEs) and safety laboratory results.

Immunologic tests. The development of antipeptide antibodies against ATX-MS-1467 during the course of the study was measured by a solid-phase ELISA of plasma separated from blood samples collected at visits 1, 8, and 9. Bound antibody was detected with anti-human $\mathrm{k}$ light-chain antibody coupled to horseradish peroxidase. HLA-DRB1 alleles were defined by low-resolution typing using a standard single-strand conformation polymorphism PCR technique on DNA extracted from peripheral blood leukocytes. Changes in the immune response to self or foreign antigens following ATXMS-1467 dosing was monitored in a kinetic assay in vitro. ${ }^{19}$ Peripheral blood mononuclear cells (PBMC) were isolated from citrated blood samples collected at screening (visit 1), prior to dosing at visits 3-7, and at follow-up (visits 8 and 9) and stored under liquid nitrogen. PBMC were thawed, and cultures (750,000 cells/well, 48-well plate) were established in the presence of self-antigens human MBP $(50 \mu \mathrm{g} / \mathrm{mL})$, ATX-MS$1467(20 \mu \mathrm{g} / \mathrm{mL})$, or purified protein derivative of Mycobacterium tuberculosis (PPD, a component of the bacillus Calmette-Guérin [BCG] vaccine, $50 \mu \mathrm{g} / \mathrm{mL}$ ). Negative control wells contained no antigen. Responses to antigens were monitored over a period of 10 days. At days 2, 4, 6, 8, and 10, duplicate aliquots of the cell suspensions were removed and pulsed with ${ }^{3} \mathrm{H}$-thymidine to assess cell proliferation, as previously described. ${ }^{20}$ At the same time points, samples of culture supernatant were collected to determine the level of secreted cytokines (CBA human Th1/Th2 cytokine kit, BD Biosciences, Oxford, UK). RNA was extracted from the remaining cells with TRIzol (Life Technologies, Paisley, UK) and reverse transcribed with Superscript III Rnase $\mathrm{H}^{-}$Reverse Transcriptase (Life Technologies), and copy number of IFN- $\gamma$, tumor necrosis factor $\alpha$, and IL-10 cytokines was estimated by quantitative real-time PCR. ${ }^{21}$ To account for differences in RNA input copy number and complementary DNA synthesis, cytokine gene induction was expressed as relative copy number normalized to the housekeeping gene $\beta-2$ microglobulin.

MRI. Gadolinium-enhanced MRI brain scans to monitor inflammation of the CNS were performed at screening (visit 1) and repeated prior to the fifth and sixth doses (visits 6 and 7), with a further scan 1 month after the last dose (visit 8), according to local clinical practice. All patients were scanned on a $1.5 \mathrm{~T} \mathrm{Phi-}$ lips Gyroscan ACS-NT (Philips Healthcare, Guildford, UK). Conventional T2-weighted axial views of the whole brain were obtained in all patients together with gadolinium-enhanced T1-weighted scans. The scans were assessed by a consultant neuroradiologist, and each scan was compared with previous images to detect evidence of new disease activity.
Statistical analysis. EAE. Time to onset of disease was defined as the first day with a nonzero disease score; statistical analysis was by the log-rank test. Disease duration was defined as the number of days between the first and last nonzero disease scores. Animals that did not get disease during the study period were excluded; statistical analysis was by the log-rank test. The mean maximum disease score was calculated for each treatment group; statistical analysis was by exact Wilcoxon rank sum tests and compared each treatment group to PBS.

First-in-human study. Summary statistics by dose level were produced for vital signs, ECG, clinical chemistry, autoantibody analysis, hematology, and urinalysis together with changes from baseline. The small cohort of 6 patients limited statistical analysis of the immunology data.

Classification of evidence. This study provides Class IV evidence that ATX-MS-1467 is safe and tolerated in a group of 6 patients with SPMS.

RESULTS ATX-MS-1467 a combination of apitopes from MBP. HLA restriction of MBP-reactive T-cell clones, derived from HLA-DR2-positive individuals, ${ }^{14}$ was tested for recognition of ATX-MS-1467 epitopes using L-cell fibroblasts transfected with DQ6, DR2a, or DR2b genes. Among the 5 regions of MBP most frequently recognized by $\mathrm{T}$ cells from patients with MS (table 1), 4 peptides were presented to relevant T-cell clones by both live and fixed APC and were defined as apitopes. The exception was the epitope within the 150-170 region. T cells specific for the 156-170 epitope did not respond to peptide presented by fixed APC. T-cell clones specific for MS1 and MS4 recognized antigen presented by DQ6 L-cell transfectants, whereas MS7-specific $\mathrm{T}$ cells were restricted by DR2b. T-cell clones specific for peptides from the 135-159 region recognized 2 distinct minimal epitopes (140-148 or 142-152); these were restricted by DR2b and DR2a, respectively.

Peptides MS1, 4, 6, and 7 were tested for stabilization of MHC class II alleles using the Proimmune REVEAL binding assay. It is important that neither of the DQB1*0602-binding epitopes, MS1 or 4, demonstrated detectable binding to this allele (table 1). Furthermore, while MS6 contains epitopes recognized by T cells restricted by either DR2a or DR2b, this MHC binding assay did not detect any significant binding of this peptide to either DR2a (DRB5*0101) or DR2b (DRB1*1501). In marked contrast, MS7 was shown to bind well to various class II alleles, including DRB1*1501, indicating that MS7 behaves as a panDR binding epitope. These results show that MS1, 4, and 6 bind their known restriction elements (table 1) with an affinity that is below the level of detection for this peptide-MHC binding assay.

Antigen-specific immunotherapy in the (Ob $x$ DR2)F1 transgenic mouse. The (Ob x DR2)F1 mouse ${ }^{16}$ serves as an appropriate model to test ATX-MS-1467 since it expresses the MS-associated HLA-DR2b molecule 
and the Ob.1A12 T-cell receptor from a patientderived T-cell clone specific for the DR2b-bound immunodominant MBP 84-102 peptide. ${ }^{22}$ Lymphocytes from control mice responded to MBP 83-99 (MS7) in vitro by undergoing cell division and secreting IFN- $\gamma$, IL-17, and granulocyte-macrophage colony-stimulating factor (data not shown). Furthermore, studies showed that subcutaneous treatment with MS7 consistently suppressed T-cell proliferation and secretion of these 3 proinflammatory cytokines.

We tested the ability of the ATX-MS-1467 peptide cocktail to both prevent and treat ongoing disease in the (Ob x DR2)F1 mouse. As shown in figure 1, A and $\mathrm{B}$, subcutaneous administration of ATX-MS1467 suppressed the mean maximum EAE in both male $(p<0.001)$ and female mice $(p<0.004)$ while delaying mean day to onset $(p<0.001$ for both sexes). Treatment with ATX-MS-1467 after disease onset markedly inhibited mean maximum $\operatorname{EAE}(p<$ $0.011[10 \mu \mathrm{g}], p<0.001$ [33 and $100 \mu \mathrm{g}$ ]) and similarly reduced disease duration $(p<0.089$ $[10 \mu \mathrm{g}], p<0.009$ [33 $\mu \mathrm{g}$ ], and $p<0.001$ $[100 \mu \mathrm{g}])$ in a dose-dependent manner (figure 1C). Most importantly, treatment with ATX-MS-1467 reduced both mean maximum score $(p<0.001)$ and disease duration $(p<0.001)$, whereas treatment with GA did not affect either mean maximum score $(p<$ 0.316 ) or disease duration $(p<0.324)$ (figure 1D).

Phase 1 clinical trial of antigen-specific immunotherapy in SPMS: Clinical assessments. Six patients with SPMS entered the trial with EDSS scores ranging from 5 to 7.5; all patients completed the treatment regimen. The patients expressed a broad distribution of HLADR alleles-DRB1*01, DRB1*04, DRB1*07, DRB1*11, DRB1*13, DRB1*14, and DRB1*15representing $77 \%$ of Caucasian HLA haplotypes. ATX-MS-1467 was well-tolerated in all patients, with no major local reactions noted. AEs reported during the study are shown in table 2 . These were not linked consistently to the time of injection, and the patients continued to receive the investigational medicinal product (IMP) with no further recurrence of the described AEs. Two of the 14 AEs, muscle spasms and decreased ability in both legs (affecting 1 patient), were possibly related to the study but resolved within 2 days. The remaining AEs were considered to be unrelated to the study drug.

One serious AE was reported during the trial and involved hospitalization of a male patient with a urinary tract infection (attributed to intermittent

Figure 1 Treatment with ATX-MS-1467 suppresses EAE when given before or after disease onset
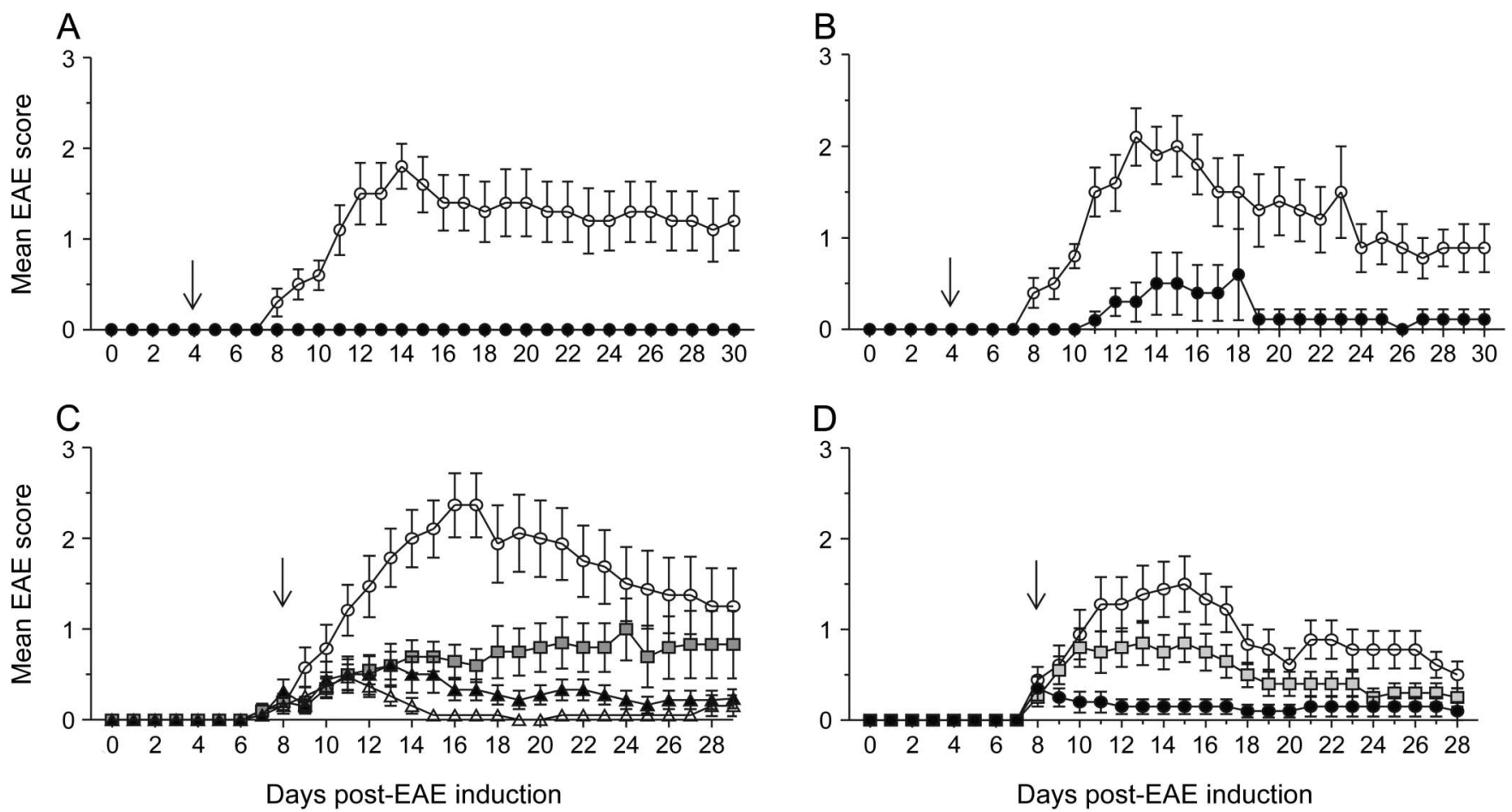

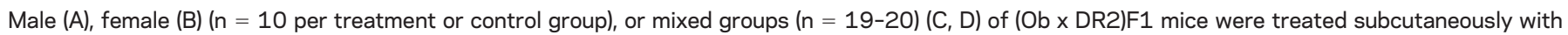

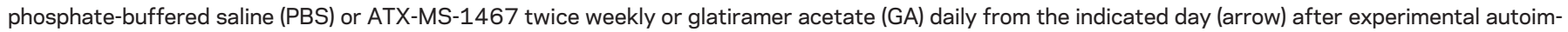

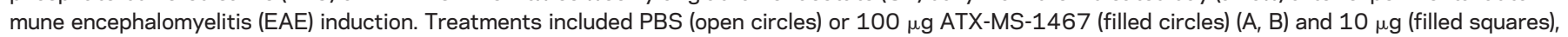

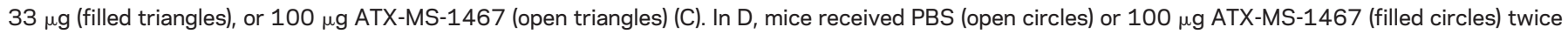
weekly or $2 \mathrm{mg} \mathrm{GA}$ daily (gray squares). Results depict mean disease score $\pm \mathrm{SEM}$. 
Table 2 Summary of adverse events

\begin{tabular}{|c|c|c|c|c|c|c|c|c|c|}
\hline \multirow[b]{2}{*}{ AEs } & \multicolumn{6}{|l|}{ Dosing } & \multirow{2}{*}{$\begin{array}{l}\text { Total no. } \\
\text { AEs }\end{array}$} & \multirow{2}{*}{$\begin{array}{l}\text { No. patients } \\
\text { reporting AE }\end{array}$} & \multirow{2}{*}{$\begin{array}{l}\text { Possibly } \\
\text { related to } \\
\text { study drug }\end{array}$} \\
\hline & $25 \mu \mathrm{g}$ & $50 \mu \mathrm{g}$ & $100 \mu \mathrm{g}$ & $400 \mu \mathrm{g}$ & $800 \mu \mathrm{g}(\mathrm{I})$ & $800 \mu \mathrm{g}$ (II) & & & \\
\hline No. AEs & 0 & 3 & 1 & 3 & 3 & 4 & 14 & 5 & \\
\hline Fatigue & 0 & $1^{a}$ & 0 & 0 & $1^{b}$ & $2^{a}$ & 4 & 3 & No \\
\hline $\begin{array}{l}\text { Gait } \\
\text { disturbance }\end{array}$ & 0 & 0 & 0 & $1^{\mathrm{a}}$ & 0 & 0 & 1 & 1 & Yes \\
\hline Herpes simplex & 0 & 0 & 0 & 0 & $1^{b}$ & 0 & 1 & 1 & No \\
\hline $\begin{array}{l}\text { Urinary tract } \\
\text { infection }\end{array}$ & 0 & 0 & 0 & $1^{c}$ & 0 & 0 & 1 & 1 & No \\
\hline Muscle spasms & 0 & & 0 & $1^{a}$ & 0 & 0 & 1 & 1 & Yes \\
\hline $\begin{array}{l}\text { Musculoskeletal } \\
\text { chest pain }\end{array}$ & 0 & $1^{a}$ & 0 & 0 & 0 & 0 & 1 & 1 & No \\
\hline $\begin{array}{l}\text { Vertigo, } \\
\text { positional }\end{array}$ & 0 & 0 & 0 & 0 & $1^{\mathrm{a}}$ & 0 & 1 & 1 & No \\
\hline $\begin{array}{l}\text { Fecal } \\
\text { incontinence }\end{array}$ & 0 & 0 & 0 & 0 & 0 & $1^{\mathrm{b}}$ & 1 & 1 & No \\
\hline $\begin{array}{l}\text { Joint sprain, } \\
\text { ankle }\end{array}$ & 0 & 0 & $1^{\mathrm{a}}$ & 0 & 0 & 0 & 1 & 1 & No \\
\hline Dizziness & 0 & 0 & 0 & 0 & 0 & $1^{b}$ & 1 & 1 & No \\
\hline Solar urticaria & 0 & $1^{a}$ & 0 & 0 & 0 & 0 & 1 & 1 & No \\
\hline
\end{tabular}

Abbreviations: $\mathrm{AE}=$ adverse event; I = 1st dose of $800 \mu \mathrm{g}$ at visit $6 ;$ II $=2$ 2nd dose of $800 \mu \mathrm{g}$ at visit 7 .

AEs were coded according to the Medical Dictionary for Regulatory Activities.

${ }^{a}$ Moderate AE.

${ }^{b}$ Mild AE.

${ }^{\mathrm{c}}$ Severe AE.

self-catheterization) with an accompanying worsening of mobility. He recovered to his previous condition with antibiotic treatment and continued to receive further doses with no recurrence. The event was considered unrelated to the IMP. No suspected unexpected serious adverse reactions were reported.

Clinical monitoring of vital signs showed no significant change following drug administration and during follow-up; safety blood parameters remained within normal limits; serial ECGs obtained within 24 hours after individual doses showed no clinically significant changes; and PR, QRS, and QTc intervals showed no consistent deviation from normal after individual doses. The study did not undergo any major protocol amendment.

An improvement in visual acuity in both eyes was demonstrated in 1 patient at the first follow-up visit and persisted throughout (baseline acuity: 6/24 right eye, 6/9 left eye; visit 8: 6/9 right eye, 6/6 left eye). No other significant differences in neurologic findings recorded at screening and at follow-up visits were observed. The EDSS scores for each patient were unchanged at the end of the trial.

Serial MRIs showed no evidence of worsened disease activity; 5 patients remained unchanged from baseline. An indication of a radiologic improvement was noted in 1 patient at visit 8 , but this was not associated with any improvement in the clinical symptoms of MS (data not shown).
Immunologic analyses. None of the patients displayed an antibody response to ATX-MS-1467 at screening; furthermore, no antipeptide antibodies were detected at the end of treatment (data not shown). This correlates with the lack of injection site complications or allergic manifestations during the trial.

The immunologic status of each patient was assessed by measuring lymphocyte responses (cell proliferation, cytokine RNA expression, and secretion) to $\mathrm{MBP}$, and this was compared to the response to PPD from the BCG vaccine. Although there was some variation in the response to PPD, there was no evidence that the observed changes were associated with treatment (figure 2, A-E). The response to MBP was relatively low, with only 3 of 6 patients showing a strong response to MBP at trial entry. Of note, there was no evidence that treatment with ATX-MS-1467 enhanced the response to MBP (figure 2F). None of the individuals who responded weakly to MBP at visit 1 showed an enhanced response to the protein after the trial; therefore, there is no evidence that this treatment leads to immunologic priming of MBP-specific $\mathrm{T}$ cells. The 3 individuals who responded strongly to MBP at visit 1 all showed a reduction in the response to the protein at visit 8 , as reflected in the reduced variation in response at this time point (figure $2 \mathrm{~F}$ ). Taking all of the patients together, there was a 
Figure 2 PBMC proliferation and cytokine secretion in response to self- and nonself-antigens following treatment with ATX-MS-1467
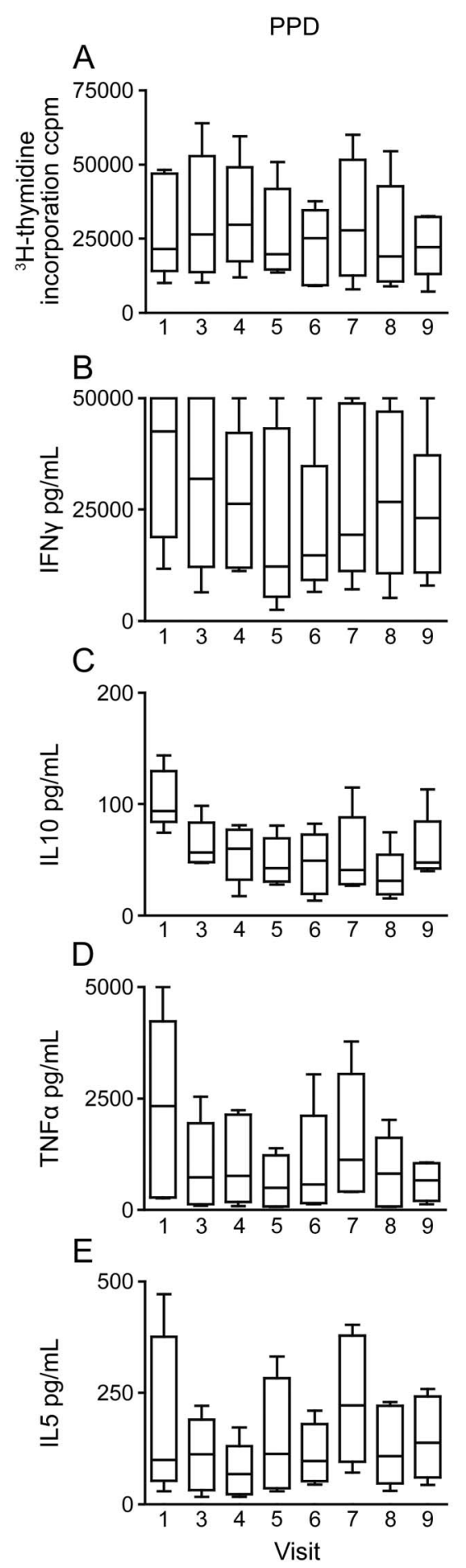

J
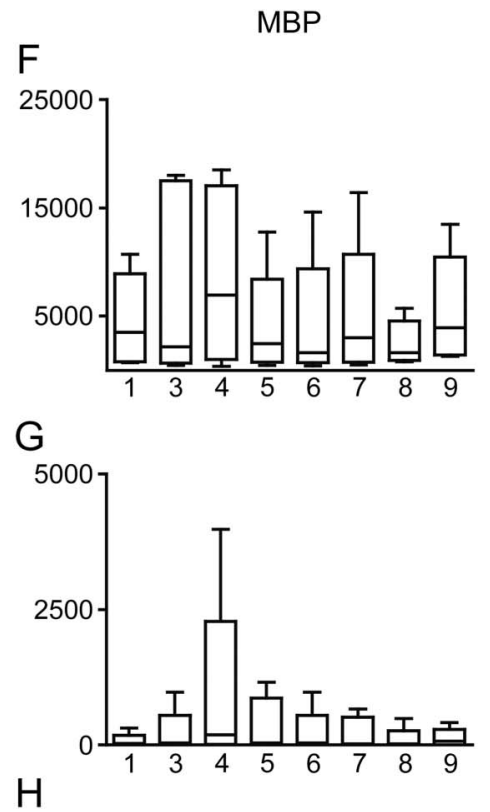

$H$

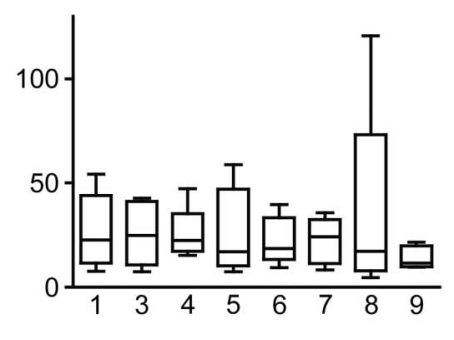

I
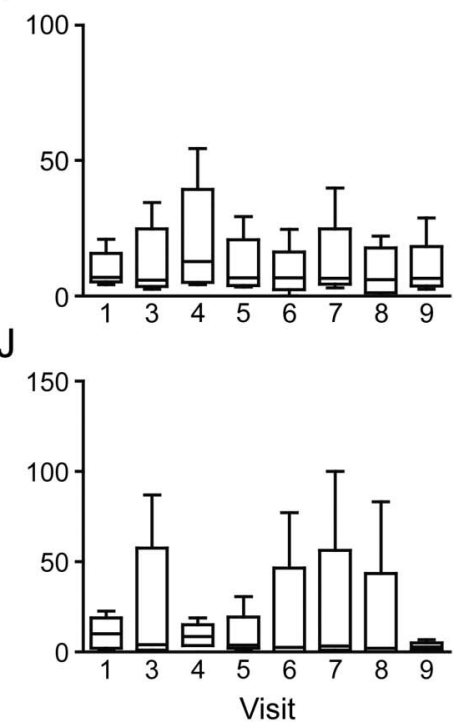

Peripheral blood mononuclear cells (PBMC) isolated from patients throughout the trial (visit 1-visit 9) were stimulated in vitro with either purified protein derivative (PPD) (nonself-antigen, A-E) or myelin basic protein (MBP) (self-antigen, F-J). Peak proliferative responses (A for PPD and $F$ for MBP) and peak cytokine secretion (B-E for PPD and G-J for MBP) were recorded for each patient at each visit. Responses to PPD were characterized by high proliferation throughout (A), high interferon (IFN)- $\gamma$ (B), and low interleukin (IL)-10 (C) secretion. IFN- $\gamma$ secretion in response to MBP (G) was very low compared to the level of proliferation (F), but IL-10 secretion was enhanced (H). Secretion of tumor necrosis factor $\alpha$ $(T N F-\alpha)$ did not increase from pretrial levels in response to either antigen $(D, I)$ and was very low with MBP stimulation. The box-and-whisker plot for each visit represents the peak responses from 6 patients. reduction in the response to MBP from visit 1 (prior to dosing) to visit 8 (1 month after the last dose).

Analysis of cytokine RNA levels revealed no overall change in the response to PPD (figure 3, A-C). Induction of RNA for inflammatory cytokines was relatively weak in response to MBP (figure 3, D and F). Analysis of IL-10 RNA revealed 3 patterns of response to peptide treatment. A DRB1*1501expressing patient showed a dose-dependent increase in IL-10 copy number in response to MBP (figure $3 \mathrm{G})$. This peaked after treatment with the highest dose of peptide and was sustained 1 month after the last dose. A similar pattern was observed in a DR13/ 14 patient, with the increase in IL-10 RNA seen in response to the ATX-MS-1467 peptide cocktail rather than MBP (figure $3 \mathrm{H}$ ). Some patients responded weakly to either MBP or the peptide cocktail (figure 3I).

DISCUSSION Treatment with a cocktail of MBP peptides can prevent EAE when given prior to disease onset. Effective treatment was associated with suppression of inflammatory cytokines and $\mathrm{T}$-cell proliferation, as previously described in other mouse models. ${ }^{8,9,23}$ Previous attempts to use peptides for treatment of ongoing disease have been complicated by allergic responses to the administered antigens. ${ }^{24-26}$ Mice immunized with peptides in strong adjuvant and then treated with soluble peptide were shown to have symptoms of anaphylaxis. This is not the case in our experiments because we induced EAE using protein antigen rather than peptide. Immunization with peptide antigen will result in the induction of peptide-specific immunoglobulin $\mathrm{E}$ and anaphylaxis on subsequent exposure to soluble peptide. Presumably this happens with peptide rather than protein antigen because peptides can adopt conformations that are distinct from the native protein structure and are therefore not subject to tolerance mechanisms.

GA is a random copolymer of 4 amino acids and is thought to modify the function of MBP-reactive $\mathrm{T}$ cells. GA reduces relapse rate and improves disability in patients with relapsing- remitting $\mathrm{MS}^{27}$ and reduces the severity of disease in mouse models of EAE. ${ }^{28,29}$ In our double transgenic model, daily injection of GA did not have a significant effect, whereas treatment with ATX-MS-1467 at 1/20th the dose led to an immediate inhibition of disease progression. Previously, GA has been most effective in inhibiting EAE when combined with antigen in the same inoculum, implying that it functions by either direct MHC blockade or modulating $T$ cells cross-reactive with MBP to the Th2 phenotype. Administration of specific antigens, such as ATX-MS-1467, is clearly more effective in the treatment protocol tested here, 

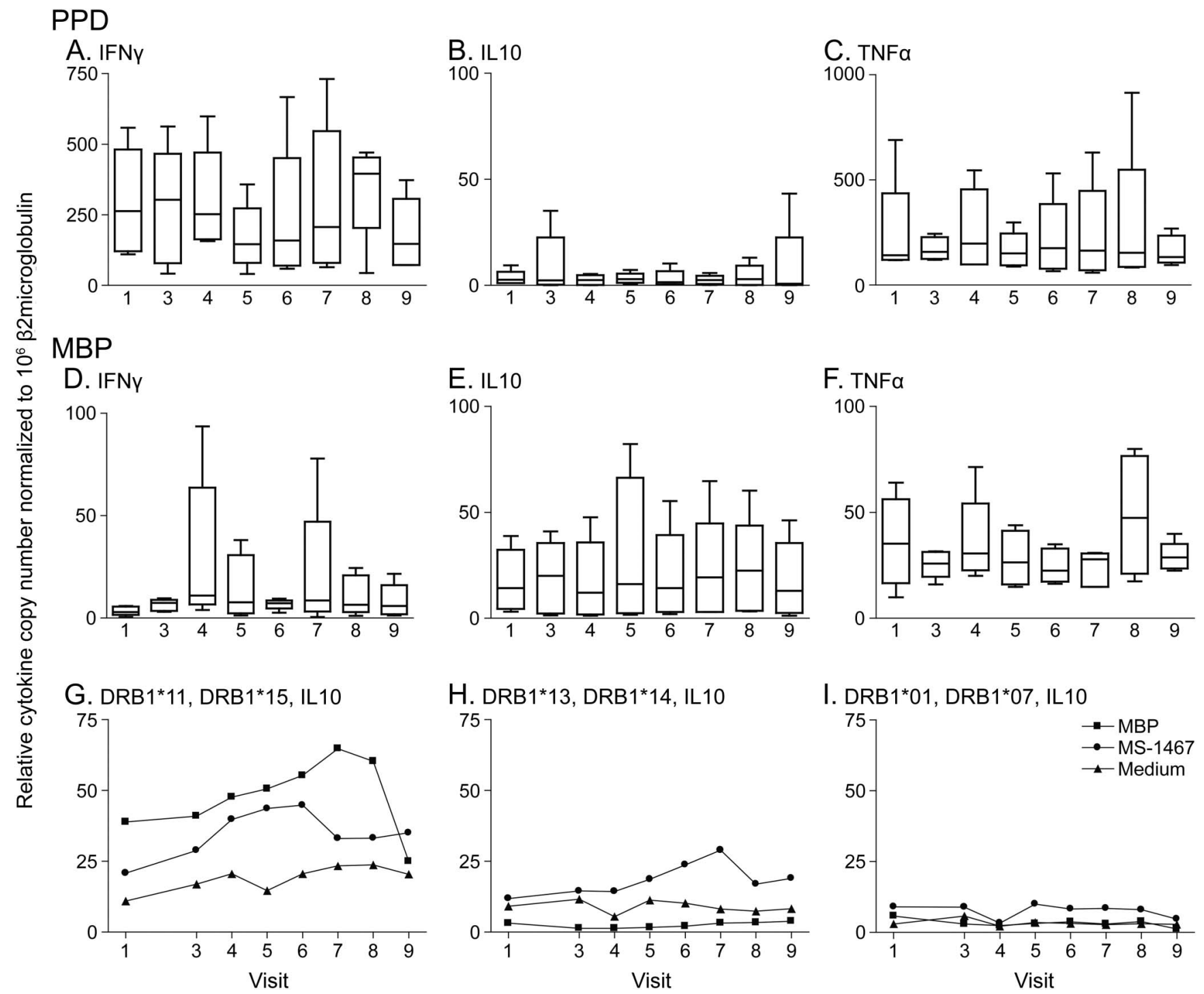

Cytokine messenger RNA transcripts were isolated from peripheral blood mononuclear cell (PBMC) cultures described in figure 2 and analyzed by quantitative real-time PCR (A-F). The box-and-whisker plot for each visit represents the peak responses from 6 patients. High levels of interferon (IFN)- $\gamma$ and tumor necrosis factor $\alpha$ (TNF- $\alpha$ ) gene expression (A, C) correlated with high levels of secreted cytokines in response to purified protein derivative (PPD). Low transcript levels of IFN- $\gamma$ (D) and TNF- $\alpha$ (F) in response to myelin basic protein (MBP) and interleukin (IL)-10 (B) in response to PPD reflected the low levels of cytokine secretion. Analysis of individual patient responses to either MBP or ATX-MS-1467 revealed that only 1 individual, expressing DRB1*15, transcribed IL-10 in response to both MBP and ATX-MS-1467 (G-I).

in which the desired effect is to modify the function of previously primed rather than naive lymphocytes.

The dosing regimen for the phase 1 clinical study was based on successful protocols from the field of allergy. Doses of peptide mixtures escalating to 50 or $100 \mu \mathrm{g}$ have been administered safely with clear therapeutic efficacy. ${ }^{30,31} \mathrm{~T}$ cells specific for selfantigens, such as MBP, will have been subjected to repertoire selection in the thymus such that the residual repertoire of cells specific for self-antigens will be of low avidity. Three of the 4 MBP peptides in ATXMS-1467 display low affinity for MHC (table 1). This is not unexpected based on previous work from our own $^{32}$ and other groups ${ }^{33,34}$ showing that $\mathrm{T}$ cells specific for low-affinity epitopes escape purging in the thymus. MS7 is a clear exception to this rule; however, this epitope contains a processing site for asparagine endopeptidase. Central tolerance to this pathogenic epitope is reduced because destructive processing limits its display in the thymus. ${ }^{35}$ We reasoned that, given the low avidity of MBP recognition, it would be necessary to administer relatively high doses of ATX-MS-1467. A further consideration for effective immunotherapy is peptide solubilitypeptides must be soluble to induce effective tolerance, as shown in models of hemolytic anemia. ${ }^{36}$ We chose $800 \mu \mathrm{g}$ per treatment as the upper dose to ensure absolute solubility and hence safety of the protocol. 
The phase 1 trial in a group of 6 patients with SPMS was successful; the treatment was welltolerated and there were changes in some patients consistent with a clinical effect of treatment. In contrast to previous peptide studies, ${ }^{24,37}$ treatment with ATX-MS-1467 did not result in any unexpected safety signals, enhance disease, or induce allergic complications. Administration of an analogue of the MBP 83-99 peptide (NBI-5788) caused an immediate hypersensitivity reaction following repeated dosing at greater than $5 \mathrm{mg}$ per dose. ATX-MS-1467 also includes MBP 83-99; however, no unexpected side effects arose in this study. There are 2 explanations. First, ATX-MS-1467 administration followed a doseescalation protocol. As explained elsewhere, peptide dose escalation induces a sequential desensitization of antigen-specific lymphocytes. ${ }^{38}$ This allows the safe administration of high doses of antigen while protecting the recipient from side effects. Second, the maximal dose of each individual peptide in ATX-MS-1467 was $>25$-fold lower than that previously used in the NBI-5788 trials.

Immunologic analysis of PBMC from this phase 1 study did not reveal any surprising changes. The fact that responses to PPD remained robust demonstrates that ATX-MS-1467 does not have a nonspecific immunosuppressive effect. The immune response to MBP was neither dramatically enhanced nor inhibited; however, the proliferative response to MBP was reduced at visit 8,1 month after the last dose, and then increased at 3 months. This correlated with a trend toward higher levels of IL-10 gene expression at visit 8 . However, this study group is too small to draw conclusions concerning the efficacy of this treatment in humans.

ATX-MS-1467 has been shown to be effective for both prevention and treatment of disease in a humanized mouse model of MS. Furthermore, the treatment protocol described was safe and well-tolerated in a group of 6 patients with SPMS and therefore warrants further investigation in the relapsing-remitting form of MS.

\section{AUTHOR CONTRIBUTIONS}

Dr. Streeter: study concept and design; acquisition, analysis, and interpretation of data; critical revision of the manuscript. Dr. Rigden: acquisition, analysis, and interpretation of data. Dr. Martin: study concept and design; critical revision of the manuscript. Prof. Scolding: study concept and design; acquisition, analysis, and interpretation of data; critical revision of the manuscript. Prof. Wraith: study concept and design; acquisition, analysis, and interpretation of data; critical revision of the manuscript

\section{ACKNOWLEDGMENT}

The authors thank S.K. Pillai, MD, who recruited patients for this study; Kirsty Nicolson, Louise Falk (University of Bristol), and Leigh Keen (NBS, Bristol) for technical assistance; Jan Steiner (Oxford Therapeutics Consulting), medical monitor; Carla Bennet (Gregory Fryer Associates), project manager; Carole Copestake and Denise Owen (North Bristo
NHS Trust); and most of all the patients who volunteered for this trial. Statistical analysis of EAE experiments by Richard Brammar, RenaSci Ltd.

\section{STUDY FUNDING}

UK clinical study was sponsored by Apitope Technology Bristol Ltd, Bristol, UK, supported by a Wellcome Trust UTA. Nonclinical experiments supported by EMD Serono, MA, a subsidiary of Merck KGaA, Darmstadt, Germany.

\section{DISCLOSURE}

H.B. Streeter holds patents for myelin basic protein peptide composition, peptide composition, and tolerogenic peptides from myelin basic protein and was employed by and received research support from Apitope NV. R. Rigden was employed by and received research support from Apitope Technology. K.F. Martin is employed by Apitope Technology. N.J. Scolding is an assistant editor for Practical Neurology and received research support from Genzyme-Sanofi, Merck Serono, Biogen, Novartis, and The Silverman Foundation. D.C. Wraith is on the scientific advisory boards for Apitope Intl NV, Actelion Pharma, and Zealand Pharma; received travel funding from Apitope Intl NV; is a senior editor for Immunotherapy; holds patents for peptides, tolerisation-inducing composition, FVIII peptides and their use in tolerising haemophiliacs, composition, disease markers, tolerogenic peptides from myelin basic protein, peptide selection method, and improvements relating to influenza vaccine; has consulted for Apitope International NV, Peptide Therapeutics, Teva, GSK Bio, Hoffman La Roche, Novartis, DTI, and Food Standards Agency; received research support from Apitope International NV, UCB Celltech, MRC, and Wellcome Trust; holds stock and stock options with Apitope Int. NV; and was an expert witness for Geron. Go to Neurology. $\mathrm{org} / \mathrm{nn}$ for full disclosure forms.

Received June 23, 2014. Accepted in final form February 10, 2015.

\section{REFERENCES}

1. Giacomini PS, Darlington PJ, Bar-Or A. Emerging multiple sclerosis disease-modifying therapies. Curr Opin Neurol 2009;22:226-232.

2. Garber K. Immunology: a tolerant approach. Nature 2014;507:418-420.

3. Larche M, Wraith DC. Peptide-based therapeutic vaccines for allergic and autoimmune diseases. Nat Med 2005;11: S69-S76.

4. Anderton SM, Viner NJ, Matharu P, Lowrey PA, Wraith DC. Influence of a dominant cryptic epitope on autoimmune $\mathrm{T}$ cell tolerance. Nat Immunol 2002;3:175-181.

5. Santambrogio L, Sato AK, Fischer FR, Dorf ME, Stern LJ. Abundant empty class II MHC molecules on the surface of immature dendritic cells. Proc Natl Acad Sci USA 1999; 96:15050-15055.

6. Steinman RM, Hawiger D, Nussenzweig MC. Tolerogenic dendritic cells. Annu Rev Immunol 2003;21:685-711.

7. Metzler B, Wraith DC. Inhibition of T-cell responsiveness by nasal peptide administration: influence of the thymus and differential recovery of T-cell-dependent functions. Immunology 1999;97:257-263.

8. Burkhart C, Liu GY, Anderton SM, Metzler B, Wraith DC. Peptide-induced T cell regulation of experimental autoimmune encephalomyelitis: a role for IL-10. Int Immunol 1999;11:1625-1634.

9. Gabrysova L, Nicolson KS, Streeter HB, et al. Negative feedback control of the autoimmune response through antigen-induced differentiation of IL-10-secreting Th1 cells. J Exp Med 2009;206:1755-1767.

10. Metzler B, Wraith DC. Inhibition of experimental autoimmune encephalomyelitis by inhalation but not oral administration of the encephalitogenic peptide: influence of MHC binding affinity. Int Immunol 1993;5:1159-1165. 
11. Anderton SM, Wraith DC. Hierarchy in the ability of T cell epitopes to induce peripheral tolerance to antigens from myelin. Eur J Immunol 1998;28:1251-1261.

12. Liu JQ, Bai XF, Shi FD, et al. Inhibition of experimental autoimmune encephalomyelitis in Lewis rats by nasal administration of encephalitogenic MBP peptides: synergistic effects of MBP 68-86 and 87-99. Int Immunol 1998;10:1139-1148.

13. Walczak A, Siger M, Ciach A, Szczepanik M, Selmaj K. Transdermal application of myelin peptides in multiple sclerosis treatment. JAMA Neurol 2013;70:1105-1109.

14. Mazza G, Ponsford M, Lowrey P, Campbell MJ, Zajicek J, Wraith DC. Diversity and dynamics of the T-cell response to MBP in DR2+ve individuals. Clin Exp Immunol 2002;128:538-547.

15. Fairchild PJ, Wildgoose R, Atherton E, Webb S, Wraith DC. An autoantigenic T cell epitope forms unstable complexes with class II MHC: a novel route for escape from tolerance induction. Int Immunol 1993;5:1151-1158.

16. Madsen LS, Andersson EC, Jansson L, et al. A humanized model for multiple sclerosis using HLA-DR2 and a human T-cell receptor. Nat Genet 1999;23:343-347.

17. McDonald WI, Compston A, Edan G, et al. Recommended diagnostic criteria for multiple sclerosis: guidelines from the International Panel on the diagnosis of multiple sclerosis. Ann Neurol 2001;50:121-127.

18. Kurtzke JF. Rating neurologic impairment in multiple sclerosis: an expanded disability status scale (EDSS). Neurology 1983;33:1444-1452.

19. Plebanski M, Burtles SS. In vitro primary responses of human $\mathrm{T}$ cells to soluble protein antigens. J Imm Meth 1994;170:15-25.

20. Ponsford M, Mazza G, Coad J, Campbell MJ, Zajicek J, Wraith DC. Differential responses of CD $45+$ ve T-cell subsets to MBP in multiple sclerosis. Clin Exp Immunol 2001;124:315-322.

21. Stordeur P, Poulin LF, Craciun L, et al. Cytokine mRNA quantification by real-time PCR. J Immunol Methods 2002;259:55-64.

22. Wucherpfennig KW, Zhang J, Witek C, et al. Clonal expansion and persistence of human $\mathrm{T}$ cells specific for an immunodominant myelin basic protein peptide. J Immunol 1994;152:5581-5592.

23. Sundstedt A, O’Neill EJ, Nicolson KS, Wraith DC. Role for IL-10 in suppression mediated by peptide-induced regulatory T cells in vivo. J Immunol 2003;170:1240-1248.

24. Kappos L, Comi G, Panitch H, et al. Induction of a nonencephalitogenic type $2 \mathrm{~T}$ helper-cell autoimmune response in multiple sclerosis after administration of an altered peptide ligand in a placebo-controlled, randomized phase II trial. Nat Med 2000;6:1176-1182.

25. Pedotti R, Mitchell D, Wedemeyer J, et al. An unexpected version of horror autotoxicus: anaphylactic shock to a selfpeptide. Nat Immunol 2001;2:216-222.
26. Smith CE, Eagar TN, Strominger JL, Miller SD. Differential induction of IgE-mediated anaphylaxis after soluble vs. cell-bound tolerogenic peptide therapy of autoimmune encephalomyelitis. Proc Natl Acad Sci USA 2005;102: 9595-9600.

27. Johnson KP, Brooks BR, Ford CC, et al. Sustained clinical benefits of glatiramer acetate in relapsing multiple sclerosis patients observed for 6 years. Mult Scler 2000;6:255-266.

28. Teitelbaum D, Fridkis-Hareli M, Arnon R, Sela M. Copolymer 1 inhibits chronic relapsing experimental allergic encephalomyelitis induced by proteolipid protein (PLP) peptides in mice and interferes with PLP-specific T cell responses. J Neuroimmunol 1996;64:209-217.

29. Stern JN, Keskin DB, Zhang H, Lv H, Kato Z, Strominger JL. Amino acid copolymer-specific IL-10secreting regulatory $\mathrm{T}$ cells that ameliorate autoimmune diseases in mice. Proc Natl Acad Sci USA 2008;105: 5172-5176.

30. Oldfield WL, Larche M, Kay AB. Effect of T-cell peptides derived from Fel d 1 on allergic reactions and cytokine production in patients sensitive to cats: a randomised controlled trial. Lancet 2002;360:47-53.

31. Müller U, Akdis CA, Fricker M, et al. Successful immunotherapy with T-cell epitope peptides of bee venom phospholipase A2 induces specific T-cell anergy in patients allergic to bee venom. J Allergy Clin Immunol 1998; 101:747-754.

32. Liu GY, Fairchild PJ, Smith RM, Prowle JR, Kioussis D, Wraith DC. Low avidity recognition of self-antigen by $\mathrm{T}$ cells permits escape from central tolerance. Immunity 1995;3:407-415.

33. Harrington CJ, Paez A, Hunkapiller T, et al. Differential tolerance is induced in $\mathrm{T}$ cells recognizing distinct epitopes of myelin basic protein. Immunity 1998;8:571-580.

34. Targoni OS, Lehmann PV. Endogenous myelin basic protein inactivates the high avidity $\mathrm{T}$ cell repertoire. J Exp Med 1998;187:2055-2063.

35. Manoury B, Mazzeo D, Fugger L, et al. Destructive processing by asparagine endopeptidase limits presentation of a dominant T cell epitope in MBP. Nat Immunol 2002;3: 169-174.

36. Shen CR, Youssef AR, Devine A, et al. Peptides containing a dominant $\mathrm{T}$-cell epitope from red cell band 3 have in vivo immunomodulatory properties in NZB mice with autoimmune hemolytic anemia. Blood 2003;102: 3800-3806.

37. Bielekova B, Goodwin B, Richert N, et al. Encephalitogenic potential of the myelin basic protein peptide (amino acids 83-99) in multiple sclerosis: results of a phase II clinical trial with an altered peptide ligand. Nat Med 2000;6:1167-1175.

38. Burton BR, Britton GJ, Fang H, et al. Sequential transcriptional changes dictate safe and effective antigenspecific immunotherapy. Nat Commun 2014;5:4741. 


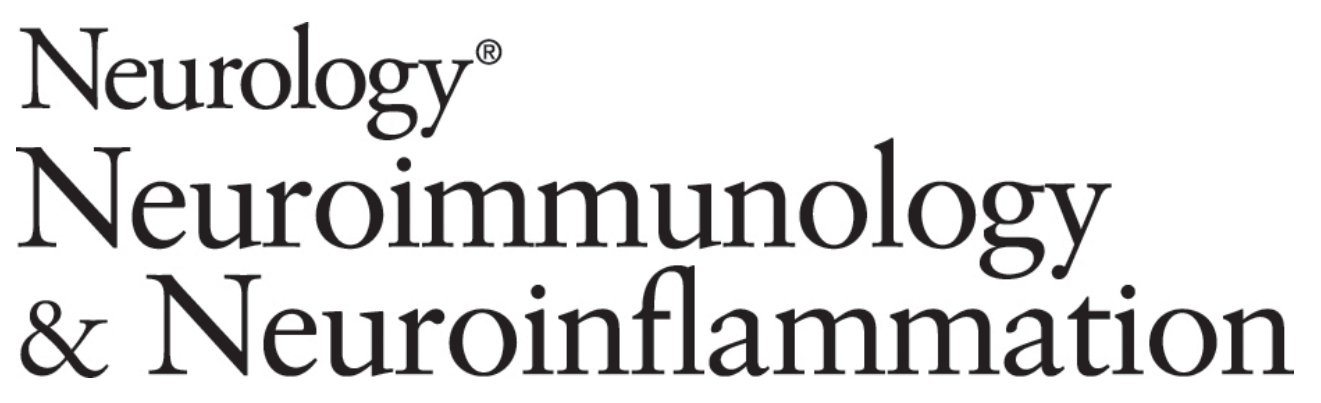
Preclinical development and first-in-human study of ATX-MS-1467 for immunotherapy of MS
Heather B. Streeter, Rachel Rigden, Keith F. Martin, et al.
Neurol Neuroimmunol Neuroinflamm 2015;2;
DOI 10.1212/NXI.0000000000000093

This information is current as of March 12, 2015

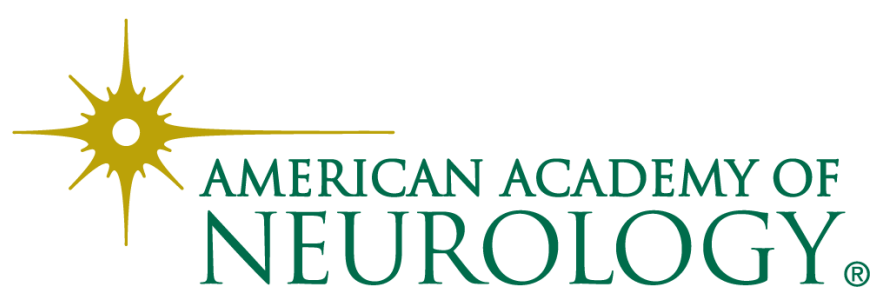




\section{Updated Information \& Services}

References

Citations

Subspecialty Collections

\section{Permissions \& Licensing}

Reprints including high resolution figures, can be found at: http://nn.neurology.org/content/2/3/e93.full.html

This article cites 38 articles, 8 of which you can access for free at: http://nn.neurology.org/content/2/3/e93.full.html\#\#ref-list-1

This article has been cited by 2 HighWire-hosted articles: http://nn.neurology.org/content/2/3/e93.full.html\#\#otherarticles

This article, along with others on similar topics, appears in the following collection(s):

All Immunology

http://nn.neurology.org//cgi/collection/all_immunology

Autoimmune diseases

http://nn.neurology.org//cgi/collection/autoimmune_diseases

\section{Class IV}

http://nn.neurology.org//cgi/collection/class_iv

Multiple sclerosis

http://nn.neurology.org//cgi/collection/multiple_sclerosis

Information about reproducing this article in parts (figures,tables) or in its entirety can be found online at:

http://nn.neurology.org/misc/about.xhtml\#permissions

Information about ordering reprints can be found online: http://nn.neurology.org/misc/addir.xhtml\#reprintsus

Neurol Neuroimmunol Neuroinflamm is an official journal of the American Academy of Neurology.

Published since April 2014, it is an open-access, online-only, continuous publication journal. Copyright $\odot$ 2015 American Academy of Neurology. All rights reserved. Online ISSN: 2332-7812.

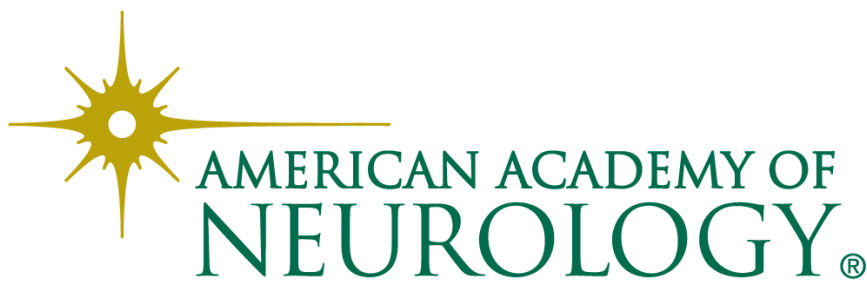

